\title{
Influence of malolactic bacteria inoculation scenarios on the efficiency of the vinification process and the quality of grape wine from the Central European region
}

\author{
Małgorzata Lasik-Kurdys $^{1} \cdot$ Małgorzata Gumienna $^{1} \cdot$ Jacek Nowak $^{1}$
}

Received: 8 February 2017 / Revised: 11 May 2017 / Accepted: 19 May 2017 / Published online: 30 May 2017

(C) The Author(s) 2017. This article is an open access publication

\begin{abstract}
The aim of this study was to evaluate the efficiency of malolactic fermentation in the production of red and white wine from high-acid musts (up to $9.5 \mathrm{~g} / \mathrm{L}$ malic acid), typical for cool-climate European wine zones. Four vinification scenarios were investigated: alcoholic fermentation only, simultaneous malolactic and alcoholic fermentation, malolactic fermentation induced at the end of alcoholic fermentation, and spontaneous malolactic fermentation. Our results, confirmed in three independent wine seasons, indicate that the best results, expressed as the greatest dynamics and efficiency in the deacidification, were observed when alcoholic and malolactic fermentation was simultaneous (83.97-94.84\% reduction in malic acid). A total reduction in malic acid in such acid musts was not possible. In the co-inoculation scenario, fermentation time was significantly reduced, there was no increase in volatile acidity, and the lowest residual sugar concentrations were noted. Advantageously, the timing of the malolactic bacteria inoculation had no effect on the metabolism of such secondary metabolites as citric and acetic acids as well as on the final ethanol and glycerol concentration. It was suggest that co-inoculation of yeast and bacteria can be a very useful technique in the process of cool-climate grape wine production and also can be regarded as being applicable on industrial scale specially for very high-acid grape must.
\end{abstract}

Keywords Malolactic fermentation - Co-inoculation · High-acid must $\cdot$ Cool-climate grape wine $\cdot$ Malic acid

Małgorzata Lasik-Kurdyś

lasik@up.poznan.pl

1 Poznan University of Life Sciences, Faculty of Food Science and Nutrition, Wojska Polskiego 31, Poznan, Poland

\section{Introduction}

One method for improving the quality of wine and endowing it with a specific character is malolactic fermentation (MLF). This is a process of biological deacidification of wine in which L-malic dicarboxylic acid is converted to L-lactic monocarboxylic acid. This process involves decarboxylation leading to a low content of soft-tasting lactic acid and $\mathrm{CO}_{2}$ saturation [11, 12, 15, 21, 25, 41]. Besides the main metabolic pathway aimed at reducing acidity, the malolactic bacteria (MLB) engage in the syntheses of other secondary metabolites that have beneficial effects on the flavor and taste of wine (higher alcohols, aldehydes, esters) $[6,10,28,35]$ and enhance its microbiological stability (bacteriocin-like inhibitory substances) [38, 42].

The bioconversion of malic to lactic acid is a secondary fermentation which, under natural conditions, takes place after completion of the alcoholic fermentation. The difficult conditions in the environment of young wine caused by high alcohol concentration, the presence of $\mathrm{SO}_{2}$, low levels of nutrients, high acidity, and low temperature can weaken or inhibit the activity of malolactic bacteria [23, 24, 38]. Thus, in order to ensure complete proper secondary fermentation, the must is inoculated with selected bacterial preparations (such as Oenococcus oeni) $[9,11,15,20]$. In industrial winemaking practice, the MLF process is also initiated after completion of alcoholic fermentation (widely discussed in the literature). The yeast cells lose their activity and undergo autolysis, leading to the release of nutrients accumulated in them. In this way, the young wine is enriched in vitamins, amino acids, proteins, and polysaccharides, which should stimulate bacterial growth $[2,4,15,20]$. The most important advantages of the sequential realization of these two 
types of fermentation are the elimination of adverse interactions between bacteria and yeast and a reduction in the risk of overproduction of undesirable metabolites, such as acetic acid (related to a low concentration of residual sugars), and other metabolites, like biogenic amines and ethyl carbamate $[3,22,26,27,32,40]$. However, problems with the proper initiation and control of the process of wine production in the classical system have prompted a search for new alternative methods of MLF induction. The laboratory-scale studies carried out to date have considered the effects of a range of inoculation timings. The bacteria can be introduced together with the yeast (co-inoculation), at the beginning of the alcoholic fermentation, in the middle of the process, or at its end [1, 2, 14-19, 31, 37]. However, the results are inconsistent and deal with the processing of grapes with significantly lower concentrations of malic acid (1.6-6.5 g/L) than the grapes used in our study $(6.54-9.5 \mathrm{~g} / \mathrm{L})$. The acidity of grape must and the concentration of malic acid in our data are significantly higher than presented elsewhere in the literature. No published data have been found so far for vinification process of such high-acid grape musts. Our work was performed in three winemaking seasons, using one $O$. oeni strain (suited to low-pH must) and four different cultivars of white and red grapes originating from Polish vineyards, in the region of Central Europe belonging to zone $\mathrm{A}$-the coldest area in the European Union winegrowing zones.

The aim of this study was: (1) to examine the course and the efficiency of MLF in four variants of winemaking process: alcoholic fermentation alone (AF), co-inoculation of yeast and bacteria (COI), sequential inoculation (SEQI), and spontaneous malolactic fermentation (SPONT); (2) to investigate the influence of the tested variants on the basic enological parameters affecting wine quality; (3) to select the best scenario for vinification of grape cultivars characterized by elevated levels of malic acid.

\section{Materials and methods}

\section{Microorganisms}

Commercially available preparates were chosen for vinification process: yeast Saccharomyces cerevisiae (Lalvin EC-118, Lallemand, USA) and bacteria O. oeni (Lalvin VP41, Lallemand, USA). One $O$. oeni preparate (suited to low-pH must) was used to avoid the additional factor (different microorganisms) influencing the course of malolactic vinification process and the quality of the obtained wines. The rehydration process was performed according to product specification.

\section{Grape musts and vinification process parameters}

Two white (Chardonnay and Kerling) and two red (Rondo and Pinot noir) grape varieties were chosen in three different wine seasons $(2009,2010$, and 2012) for grape wine production. The grapes were obtained from Mierzecin Vineyard in Poland. The vinification process was conducted in 15-L glass containers as laboratory-scale experiment.

Four different variants of vinification process were performed: (1) AF-only alcoholic fermentation (as control), (2) co-inoculation (COI) - as simultaneous inoculation of yeast and bacteria, (3) sequential inoculation (SEQI)malolactic fermentation induced at the end of alcoholic fermentation, and (4) spontaneous malolactic fermentation (SPONT) without MLB inoculation.

The inoculation of yeast was done for all variants in the first day of vinification. Malolactic bacteria inoculation was dependent on the evaluated variant: in co-inoculation (in the first day) and for sequential inoculation (after 7 days of winemaking process). To avoid the MLF in the variant of AF (alcoholic fermentation alone), an additional sulfitation process was performed (after 1 month of vinification, $10 \mathrm{~g}$ of $\mathrm{K}_{2} \mathrm{~S}_{2} \mathrm{O}_{5} / \mathrm{h} \mathrm{L}$ ). Whereas spontaneous malolactic fermentation was performed without MLB inoculation, only common treatments for inducing this process were performed (general lower sulfitation, microoxygenation, and bacteria nutrient supplementation). The detailed schedule for all variants is presented in Table 1.

\section{Chemical analysis of musts and wines}

The soluble solids in grape musts were measured by refractometer $\left({ }^{\circ} \mathrm{Bx}\right)$. The value of $\mathrm{pH}$ was evaluated according to OIV-MA-AS313-15, total acidity according to OIV-MAAS313-01, and volatile acidity according to OIV-MAAS313-02 [36]. The concentration of sugars (glucose and fructose), organic acids (malic acid, lactic acid, and citric acid), ethanol, and glycerol was established using HPLC (Waters Alliance 2695 equipped with BioRad Aminex HPX-87H column, $300 \times 7.8 \mathrm{~mm}$, and RI detector; eluent: $1.5 \mathrm{~m} \mathrm{M} \mathrm{H}_{2} \mathrm{SO}_{4}$, flow rate: $0.4 \mathrm{~mL} / \mathrm{min}$, column temp. $50{ }^{\circ} \mathrm{C}$, and detector temp. $45^{\circ} \mathrm{C}$ ).

Samples purposed for HPLC analysis were frozen. Next, directly before analysis samples were defrosted, appropriately diluted, and filtered with $0.45-\mu \mathrm{m}$ Millipore filters.

\section{Statistical analysis}

The presented data are mean values of three replications \pm SD. The significant differences between samples were analyzed using PQ Stat Software (Tukey test, $P<0.05)$. 
Table 1 Schedule of white and red wine production

\section{AF COI SEQI SPONT}

First day (temp. $20-22{ }^{\circ} \mathrm{C}$ )

White wine

Crushing and destemming, pressing

Sulfitation ( $\mathrm{g} \mathrm{K}_{2} \mathrm{~S}_{2} \mathrm{O}_{5} / \mathrm{h} \mathrm{L}$ )

Yeast inoculation $(30 \mathrm{~g} / \mathrm{h} \mathrm{L})$

Bacteria inoculation $(1 \mathrm{~g} / \mathrm{h} \mathrm{L}) *$

Red wine

Crushing and destemming,

Sulfitation $\left(\mathrm{g} \mathrm{K}_{2} \mathrm{~S}_{2} \mathrm{O}_{5} / \mathrm{h} \mathrm{L}\right)$

Yeast inoculation $(30 \mathrm{~g} / \mathrm{h} \mathrm{L})$

Bacteria inoculation $(1 \mathrm{~g} / \mathrm{h} \mathrm{L})^{\mathrm{a}}$

After 7 days (temp. $20-22{ }^{\circ} \mathrm{C}$ )

White wine

\section{Racking}

Bacteria inoculation $(1 \mathrm{~g} / \mathrm{h} \mathrm{L})$

Microoxygenation

Nutrient supplementation for bacteria $^{\mathrm{b}}$

Red wine

Pressing

Bacteria inoculation $(1 \mathrm{~g} / \mathrm{h} \mathrm{L})$

Microoxygenation

Nutrient supplementation for bacteria**

After first month (temp. $15-17^{\circ} \mathrm{C}$ )

Racking

Sulfitation ( $\mathrm{g} \mathrm{K}_{2} \mathrm{~S}_{2} \mathrm{O}_{5} / \mathrm{h} \mathrm{L}$ )

After 3 months (temp. $7-10{ }^{\circ} \mathrm{C}$ )

Racking

Sulfitation $\left(\mathrm{g} \mathrm{K}_{2} \mathrm{~S}_{2} \mathrm{O}_{5} / \mathrm{h} \mathrm{L}\right.$ )

After 6 months (temp. $7-10{ }^{\circ} \mathrm{C}$ )

Racking

Bottling

$+\quad+\quad+$

$\begin{array}{llll}5 & 5 & 5 & 3\end{array}$

$++++$

- + - -

$+\quad+\quad+$

$\begin{array}{llll}5 & 5 & 5\end{array}$

$++++$

- + - -

$+\quad+\quad+$

- -+ -

$\begin{array}{llll}- & - & -\end{array}$

$\begin{array}{llll}- & - & -\end{array}$

$+\quad+\quad+$

- -+ -

- $-\quad-\quad+$

$\begin{array}{llll}- & - & \end{array}$

$+\quad+\quad+$

$10^{\mathrm{c}}-\quad-\quad$

$+\quad+\quad+$

$\begin{array}{llll}3 & 3 & 3 & 3\end{array}$

$+\quad+\quad+$

$++++$

\section{Results and discussion}

\section{Characteristics of cool-climate grapes}

The different climatic conditions determine very significantly the chemical composition of fruits/grapes. According to wine production in European Union 21, wine-producing countries are divided into zones depending on the climate (average temperature, exposition on sun, humidity, etc.). The north part of Europe (Poland, Germany, Czech Republic, Belgium, and others) belongs to the zone A, where the climatic conditions for vine growing are the most difficult-these are cool-climate countries. Other zones (from B, through CI, CII, CIIIa, to CIIIb) include countries with different climatic conditions (coming from north to south part, directing to warmer climate). This division was made to regulate certain aspects of winemaking with consideration to the climate influence on the grapes quality [24, 33].

An important indicator of the maturity of grapes is the ratio of glucose to fructose [38]. At a value of about 1:1, the grapes have reached full physiological maturity. Unripe grapes have higher glucose content, while overripe grapes have a higher fructose levels. In our study, the grapes collected in the 2010 season had not reached maturity, as they showed a higher content of glucose, with a glucose-tofructose ratio of 1:0.88. In grapes from other winemaking seasons, the ratio varied from 1:0.96 to 1:0.98, indicating physiological and technological maturity (Table 2). The sugar concentration of the 2010 grapes was also significantly lower $\left(20.5 \pm 0.1^{\circ} \mathrm{Bx}\right)$ than in the 2009 and 2012 grapes (22-24 $\pm 0.2^{\circ} \mathrm{Bx}$ ) (Table 2 ).

The acidity of the studied grapes was typical of grapes from cool-climate regions. However, it must be emphasized that both the total acidity $(9.38-12.14 \mathrm{~g} / \mathrm{L})$ and the malic acid concentration (6.54-9.5 g/L) were higher than other grapes presented in the literature (Table 2) $[1,8,14,18,19$, $30,34,39,43]$.

a After $24 \mathrm{~h}$ of sulfitation

b Optimalo Plus (Lallemand, USA) $20 \mathrm{~g} / \mathrm{h} \mathrm{L}$

${ }^{c}$ For inhibiting MLF in the variant of AF

Table 2 Characteristic of grape must used for vinification processes

\begin{tabular}{|c|c|c|c|c|c|}
\hline & Chardonnay 2009 & Pinot noir 2009 & Kerling 2010 & Pinot noir 2012 & Rondo 2012 \\
\hline${ }^{\circ} \mathrm{Bx}$ & $22.5 \pm 0.1$ & $24.0 \pm 0.2$ & $20.5 \pm 0.1$ & $22.0 \pm 0.1$ & $22.0 \pm 0.2$ \\
\hline Sugars: glucose + fructose $(\mathrm{g} / \mathrm{L})$ & $193.12 \pm 2.11$ & $203.54 \pm 3.05$ & $171.33 \pm 2.54$ & $185.47 \pm 3.17$ & $181.62 \pm 2.84$ \\
\hline Glucose/fructose & $1: 0.98$ & $1: 0.96$ & $1: 0.88$ & $1: 0.97$ & $1: 0.96$ \\
\hline $\mathrm{pH}$ & $3.31 \pm 0.03$ & $3.64 \pm 0.05$ & $3.19 \pm 0.03$ & $3.41 \pm 0.06$ & $3.26 \pm 0.07$ \\
\hline Total acidity $^{\mathrm{a}}(\mathrm{g} / \mathrm{L})$ & $11.64 \pm 0.12$ & $9.38 \pm 0.09$ & $12.14 \pm 0.14$ & $10.95 \pm 0.23$ & $11.52 \pm 0.26$ \\
\hline Malic acid $(g / L)$ & $8.14 \pm 0.09$ & $6.54 \pm 0.07$ & $9.5 \pm 0.05$ & $8.11 \pm 0.14$ & $7.83 \pm 0.21$ \\
\hline Citric acid (g/L) & $0.33 \pm 0.02$ & $0.28 \pm 0.02$ & $0.41 \pm 0.02$ & $0.35 \pm 0.02$ & $0.31 \pm 0.02$ \\
\hline
\end{tabular}

Values are the mean of triplicates $\pm \mathrm{SD}$

a As tartaric acid (g/L) 


\section{Impact of MLF on alcoholic fermentation}

The production of grape wine was performed in laboratory scale $(15 \mathrm{~L}$ of volume each fermentor) which need to be taken into account when analyzing the results. The wine made from the 2010 grapes had a lower final ethanol concentration (a mean value of $11.0-11.3 \% \mathrm{v} / \mathrm{v}$ ) than that made from grapes from the other seasons (with a mean value of $12-13.3 \% \mathrm{v} / \mathrm{v}$ ) (Table 3). In all the studied vinification processes, no significant effect of MLF on the efficiency of alcoholic fermentation was noted. The highest dynamic of ethanol production was observed during first week of vinification process (Table 3). After this time, the ethanol concentration changed only very slightly. The final concentrations of ethanol obtained in the vinification with alcoholic fermentation only (AF) did not differ considerably from those obtained in the other variants of the process (COI, SEQI, and SPONT) (Table 3). This result confirms the observations of other authors who have reported no disturbances to alcoholic fermentation when employing similar bacterial inoculation variants [1, 14, 19, 30, 39, 43]. Although some authors have pointed to disturbances in alcoholic fermentation attributed to the activity of malolactic bacteria, these have concerned the viability of the yeast - a reduction in their growth dynamics and metabolic activity - with no significant influence on the final ethanol content in wines [7, 34].

Besides ethanol and $\mathrm{CO}_{2}$, glycerol is also synthesized during alcoholic fermentation. This is a product of the reduction in dihydroxyacetone phosphate, and its level has a crucial effect on the final quality of wine. The concentration of glycerol depends on the grape microflora, the parameters of the vinification process, the type of yeast, the sulfitation intensity, and the temperature [11, $12,15,21,25]$. No significant influence of an inoculated secondary fermentation (COI and SEQI) on the final content of glycerol in the studied wines was observed, which agrees with the observations of Abrahamse and
Table 3 Concentration of ethanol during vinification process

\begin{tabular}{|c|c|c|c|c|c|c|}
\hline \multicolumn{7}{|c|}{ Ethanol (\% v/v) } \\
\hline & 4 days & 1 week & 2 weeks & 1 month & 3 months & 6 months \\
\hline \multicolumn{7}{|c|}{ Chardonnay 2009} \\
\hline $\mathrm{AF}$ & $6.3 \pm 0.11^{\mathrm{a}}$ & $11.3 \pm 0.27^{\mathrm{b}}$ & $11.7 \pm 0.29^{\mathrm{a}}$ & $11.9 \pm 0.17^{\mathrm{b}}$ & $12.3 \pm 0.17^{\mathrm{a}}$ & $12.5 \pm 0.22^{\mathrm{a}}$ \\
\hline COI & $5.9 \pm 0.14^{\mathrm{c}}$ & $11.5 \pm 0.31^{\mathrm{a}}$ & $11.8 \pm 0.21^{\mathrm{a}}$ & $12.1 \pm 0.20^{\mathrm{a}}$ & $12.1 \pm 0.15^{\mathrm{b}}$ & $12.3 \pm 0.34^{\mathrm{a}}$ \\
\hline SEQI & $6.1 \pm 0.08^{\mathrm{b}}$ & $11.7 \pm 0.22^{\mathrm{a}}$ & $11.7 \pm 0.27^{\mathrm{a}}$ & $11.9 \pm 0.16^{\mathrm{b}}$ & $12.2 \pm 0.16^{\mathrm{a}}$ & $12.4 \pm 0.19^{\mathrm{a}}$ \\
\hline SPONT & $6.1 \pm 0.09^{\mathrm{b}}$ & $11.4 \pm 0.17^{\mathrm{b}}$ & $11.6 \pm 0.19^{\mathrm{a}}$ & $11.9 \pm 0.19^{\mathrm{b}}$ & $12.3 \pm 0.15^{\mathrm{a}}$ & $12.5 \pm 0.12^{\mathrm{a}}$ \\
\hline \multicolumn{7}{|c|}{ Pinot noir 2009} \\
\hline $\mathrm{AF}$ & $6.9 \pm 0.12^{\mathrm{a}}$ & $12.1 \pm 0.20^{\mathrm{a}}$ & $12.4 \pm 0.17^{\mathrm{b}}$ & $12.7 \pm 0.22^{\mathrm{a}}$ & $13.0 \pm 0.22^{\mathrm{a}}$ & $13.3 \pm 0.11^{\mathrm{a}}$ \\
\hline COI & $6.6 \pm 0.16^{\mathrm{b}}$ & $12.3 \pm 0.21^{\mathrm{a}}$ & $12.6 \pm 0.07^{\mathrm{a}}$ & $12.9 \pm 0.08^{\mathrm{a}}$ & $13.1 \pm 0.08^{\mathrm{a}}$ & $13.1 \pm 0.19^{\mathrm{a}}$ \\
\hline SEQI & $6.7 \pm 0.11^{\mathrm{b}}$ & $12.1 \pm 0.18^{\mathrm{a}}$ & $12.4 \pm 0.19^{b}$ & $12.7 \pm 0.21^{\mathrm{a}}$ & $13.0 \pm 0.21^{\mathrm{a}}$ & $13.0 \pm 0.36^{\mathrm{a}}$ \\
\hline SPONT & $6.9 \pm 0.09^{\mathrm{a}}$ & $12.1 \pm 0.24^{\mathrm{a}}$ & $12.4 \pm 0.16^{\mathrm{b}}$ & $12.8 \pm 0.17^{\mathrm{a}}$ & $13.1 \pm 0.17^{\mathrm{a}}$ & $13.2 \pm 0.23^{\mathrm{a}}$ \\
\hline \multicolumn{7}{|c|}{ Kerling 2010} \\
\hline $\mathrm{AF}$ & $6.4 \pm 0.20^{\mathrm{a}}$ & $10.4 \pm 0.12^{\mathrm{a}}$ & $10.6 \pm 0.09^{\mathrm{a}}$ & $10.9 \pm 0.09^{\mathrm{a}}$ & $11.2 \pm 0.21^{\mathrm{a}}$ & $11.2 \pm 0.24^{\mathrm{a}}$ \\
\hline COI & $6.6 \pm 0.16^{\mathrm{a}}$ & $10.5 \pm 0.14^{\mathrm{a}}$ & $10.7 \pm 0.11^{\mathrm{a}}$ & $10.9 \pm 0.11^{\mathrm{a}}$ & $11.0 \pm 0.19^{\mathrm{a}}$ & $11.0 \pm 0.26^{\mathrm{a}}$ \\
\hline SEQI & $6.4 \pm 0.21^{\mathrm{a}}$ & $10.4 \pm 0.11^{\mathrm{a}}$ & $10.7 \pm 0.13^{\mathrm{a}}$ & $10.8 \pm 0.13^{\mathrm{a}}$ & $11.0 \pm 0.17^{\mathrm{a}}$ & $11.0 \pm 0.38^{\mathrm{a}}$ \\
\hline SPONT & $6.5 \pm 0.17^{\mathrm{a}}$ & $10.4 \pm 0.09^{\mathrm{a}}$ & $10.7 \pm 0.08^{\mathrm{a}}$ & $10.9 \pm 0.08^{\mathrm{a}}$ & $11.2 \pm 0.20^{\mathrm{a}}$ & $11.3 \pm 0.22^{\mathrm{a}}$ \\
\hline \multicolumn{7}{|c|}{ Pinot noir 2012} \\
\hline $\mathrm{AF}$ & $6.7 \pm 0.32^{\mathrm{a}}$ & $11.1 \pm 0.22^{\mathrm{a}}$ & $11.6 \pm 0.21^{\mathrm{a}}$ & $11.9 \pm 0.23^{\mathrm{a}}$ & $12.0 \pm 0.12^{\mathrm{a}}$ & $12.1 \pm 0.14^{\mathrm{a}}$ \\
\hline $\mathrm{COI}$ & $6.4 \pm 0.21^{\mathrm{b}}$ & $11.3 \pm 0.36^{\mathrm{a}}$ & $11.4 \pm 0.26^{\mathrm{a}}$ & $11.8 \pm 0.17^{\mathrm{a}}$ & $12.0 \pm 0.16^{\mathrm{a}}$ & $12.0 \pm 0.09^{\mathrm{a}}$ \\
\hline SEQI & $6.6 \pm 0.17^{\mathrm{a}}$ & $11.3 \pm 0.28^{\mathrm{a}}$ & $11.5 \pm 0.23^{\mathrm{a}}$ & $11.8 \pm 0.21^{\mathrm{a}}$ & $12.1 \pm 0.09^{\mathrm{a}}$ & $12.1 \pm 0.11^{\mathrm{a}}$ \\
\hline SPONT & $6.6 \pm 0.13^{\mathrm{a}}$ & $11.2 \pm 0.17^{\mathrm{a}}$ & $11.5 \pm 0.16^{\mathrm{a}}$ & $11.8 \pm 0.24^{\mathrm{a}}$ & $12.0 \pm 0.10^{\mathrm{a}}$ & $12.0 \pm 0.15^{\mathrm{a}}$ \\
\hline \multicolumn{7}{|c|}{ Rondo 2012} \\
\hline $\mathrm{AF}$ & $6.8 \pm 0.22^{\mathrm{a}}$ & $11.6 \pm 0.26^{\mathrm{a}}$ & $11.9 \pm 0.22^{\mathrm{a}}$ & $12.0 \pm 0.09^{\mathrm{a}}$ & $12.2 \pm 0.16^{\mathrm{a}}$ & $12.2 \pm 0.15^{\mathrm{a}}$ \\
\hline $\mathrm{COI}$ & $6.7 \pm 0.19^{\mathrm{a}}$ & $11.7 \pm 0.19^{\mathrm{a}}$ & $11.8 \pm 0.24^{\mathrm{a}}$ & $11.9 \pm 0.11^{\mathrm{a}}$ & $12.0 \pm 0.19^{\mathrm{a}}$ & $12.1 \pm 0.09^{\mathrm{a}}$ \\
\hline SEQI & $6.8 \pm 0.27^{\mathrm{a}}$ & $11.8 \pm 0.31^{\mathrm{a}}$ & $11.8 \pm 0.18^{\mathrm{a}}$ & $12.0 \pm 0.16^{\mathrm{a}}$ & $12.0 \pm 0.24^{\mathrm{a}}$ & $12.0 \pm 0.13^{\mathrm{a}}$ \\
\hline SPONT & $6.6 \pm 0.32^{\mathrm{a}}$ & $11.6 \pm 0.34^{\mathrm{a}}$ & $11.9 \pm 0.07^{\mathrm{a}}$ & $12.0 \pm 0.09^{\mathrm{a}}$ & $12.0 \pm 0.13^{\mathrm{a}}$ & $12.0 \pm 0.17^{\mathrm{a}}$ \\
\hline
\end{tabular}

The data are the mean of triplicates \pm SD

$(\mathrm{a}, \mathrm{b}, \mathrm{c})$ Denotes statistically significant differences $(P<0.05)$ between the different MLB inoculation scenarios 
Bartowsky [1]. Glycerol is known to be a source of carbon for microorganisms living in wine-both acetic and lactic acid bacteria can use glycerol for their metabolic processes. This particularly applies to infected grapes and musts, as well as to spontaneous processes [11, 12, $15,25]$. Similar observations were made in our study. A significantly lower concentration of glycerol was found in the wines obtained with spontaneous MLF (Table 4). It can be supposed that it is a consequence of glycerol consumption by native malolactic bacteria. However, to certify this statement some additional parameters like byproducts of microbial glycerol degradation need to be investigated.

In all the wines we produced, the concentration of residual sugars varied from 2.08 to $5.19 \mathrm{~g} / \mathrm{L}$ (Table 4); they can thus be classified as dry. The MLF process was found to have a significant effect on the residual sugar level: Significantly lower concentrations of residual sugars were noted in the wines obtained by applying the inoculated (simultaneous or sequential) MLF; this is a great advantage of these MLF processes. The lower concentration of sugars enhances the microbiological stability of the wine and protects it from microbiological synthesis of undesirable metabolites that can contribute to spoilage [34].

\section{Course and yield of malolactic fermentation}

The acidity of grapes and wine is determined by the concentration of tartaric and malic acid, considered together;
Table 4 Concentration of glycerol, residual sugars, and citric acid after 180 days of vinification

\begin{tabular}{|c|c|c|c|}
\hline & Glycerol (g/L) & Residual sugars (glucose + fructose) $(\mathrm{g} / \mathrm{L})$ & Citric acid $(\mathrm{g} / \mathrm{L})$ \\
\hline \multicolumn{4}{|c|}{ Chardonnay 2009} \\
\hline $\mathrm{AF}$ & $8.96 \pm 0.07^{\mathrm{a}}$ & $5.11 \pm 0.12^{\mathrm{d}}$ & $0.34 \pm 0.02^{\mathrm{a}}$ \\
\hline $\mathrm{COI}$ & $8.91 \pm 0.04^{\mathrm{a}}$ & $2.08 \pm 0.57^{\mathrm{a}}$ & $0.33 \pm 0.01^{\mathrm{a}}$ \\
\hline SEQI & $8.97 \pm 0.06^{\mathrm{a}}$ & $2.57 \pm 0.15^{\mathrm{b}}$ & $0.34 \pm 0.02^{\mathrm{a}}$ \\
\hline SPONT & $8.59 \pm 0.07^{b}$ & $4.87 \pm 0.11^{\mathrm{c}}$ & $\begin{array}{l}0.24 \pm 0.03^{\mathrm{b}} \\
27.27 \% *\end{array}$ \\
\hline \multicolumn{4}{|c|}{ Pinot noir 2009} \\
\hline $\mathrm{AF}$ & $9.67 \pm 0.12^{\mathrm{a}}$ & $4.85 \pm 0.16^{\mathrm{c}}$ & $0.26 \pm 0.06^{\mathrm{a}}$ \\
\hline $\mathrm{COI}$ & $9.54 \pm 0.11^{\mathrm{a}}$ & $2.17 \pm 0.05^{\mathrm{a}}$ & $0.27 \pm 0.03^{\mathrm{a}}$ \\
\hline SEQI & $9.55 \pm 0.06^{\mathrm{a}}$ & $2.39 \pm 0.08^{\mathrm{b}}$ & $0.26 \pm 0.02^{\mathrm{a}}$ \\
\hline SPONT & $9.19 \pm 0.09^{b}$ & $3.94 \pm 0.14^{\mathrm{c}}$ & $\begin{array}{l}0.17 \pm 0.05^{\mathrm{b}} \\
39.28 \% *\end{array}$ \\
\hline \multicolumn{4}{|c|}{ Kerling 2010} \\
\hline $\mathrm{AF}$ & $8.77 \pm 0.12^{\mathrm{a}}$ & $4.74 \pm 0.06^{\mathrm{c}}$ & $0.39 \pm 0.04^{\mathrm{a}}$ \\
\hline COI & $8.73 \pm 0.11^{\mathrm{a}}$ & $2.13 \pm 0.09^{\mathrm{a}}$ & $0.41 \pm 0.03^{\mathrm{a}}$ \\
\hline SEQI & $8.75 \pm 0.06^{\mathrm{a}}$ & $2.44 \pm 0.10^{\mathrm{b}}$ & $0.40 \pm 0.02^{\mathrm{a}}$ \\
\hline SPONT & $8.39 \pm 0.09^{b}$ & $4.08 \pm 0.06^{\mathrm{d}}$ & $\begin{array}{l}0.30 \pm 0.03^{\mathrm{b}} \\
26.83 \% *\end{array}$ \\
\hline \multicolumn{4}{|c|}{ Pinot noir 2012} \\
\hline $\mathrm{AF}$ & $8.89 \pm 0.11^{\mathrm{a}}$ & $5.19 \pm 0.04^{\mathrm{d}}$ & $0.33 \pm 0.0 .2^{\mathrm{a}}$ \\
\hline $\mathrm{COI}$ & $8.91 \pm 0.08^{\mathrm{a}}$ & $3.14 \pm 0.11^{\mathrm{a}}$ & $0.33 \pm 0.01^{\mathrm{a}}$ \\
\hline SEQI & $8.85 \pm 0.09^{\mathrm{a}}$ & $3.81 \pm 0.14^{\mathrm{b}}$ & $0.34 \pm 0.03^{\mathrm{a}}$ \\
\hline SPONT & $8.35 \pm 0.07^{b}$ & $4.56 \pm 0.06^{\mathrm{c}}$ & $\begin{array}{l}0.22 \pm 0.01^{\mathrm{b}} \\
37.14 \% *\end{array}$ \\
\hline \multicolumn{4}{|c|}{ Rondo 2012} \\
\hline $\mathrm{AF}$ & $8.86 \pm 0.09^{\mathrm{a}}$ & $4.47 \pm 0.08^{c}$ & $0.32 \pm 0.02^{\mathrm{a}}$ \\
\hline $\mathrm{COI}$ & $8.83 \pm 0.07^{\mathrm{a}}$ & $3.27 \pm 0.14^{\mathrm{a}}$ & $0.30 \pm 0.02^{\mathrm{a}}$ \\
\hline SEQI & $8.89 \pm 0.10^{\mathrm{a}}$ & $4.02 \pm 0.09^{\mathrm{b}}$ & $0.30 \pm 0.01^{\mathrm{a}}$ \\
\hline SPONT & $8.25 \pm 0.08^{b}$ & $5.06 \pm 016^{\mathrm{d}}$ & $\begin{array}{l}0.20 \pm 0.01^{\mathrm{b}} \\
35.48 \% *\end{array}$ \\
\hline
\end{tabular}

The data are the mean of triplicates \pm SD

* Denotes \% of citric acid reduction for spontaneous MLF

(a,b,c,d) Denotes statistically significant differences $(P<0.05)$ between the different MLB inoculation scenarios 
these make up $90 \%$ of the total content of organic acids in wine. The concentration of tartaric acid does not significantly change over the course of vinification, though it may be slightly reduced as a consequence of the metabolism of S. cerevisiae yeast and malolactic bacteria, and as a result of tartaric acid salt precipitation (known as wine stone) during cold stabilization [11, 12, 15, 21, 24, 25]. The concentration of malic acid can reach up to $10 \mathrm{~g} / \mathrm{L}$, especially in grapes grown in cool-climate regions [33], but can be reduced to zero in the MLF process. As a result of decarboxylation, $1 \mathrm{~g}$ of malic acid gives theoretically $0.67 \mathrm{~g}$ of lactic acid and $0.33 \mathrm{~g}(165 \mathrm{~mL}) \mathrm{CO}_{2}[11,15,21,23,24]$.

The course of the bioconversion of malic into lactic acid was evaluated for the studied variants of vinification processes. The highest dynamics of the conversion were observed in the Chardonnay 2009 (Fig. 1). The greatest reduction in malic acid concentration, and thus the greatest synthesis of lactic acid, was observed in the first month of the process. After this, the parameters stabilized. For the other types of the wines studied (Pinot noir, Rondo, and Kerling) the dynamics of conversion were lower and the process stabilized after 3 months of vinification (Figs. 1, 2).

The reduction in malic acid concentration with simultaneous biosynthesis of lactic acid was observed in each process. Much lower yields of MLF were noted in the variants with no bacterial inoculation (on average 19.03 and $31.17 \%$ of the theoretical yield in the alcoholic fermentation and spontaneous MLF variants, respectively) (Fig. 3). To initiate spontaneous MLF, the following specific treatments were performed: lower sulfitation, microoxygenation, and supplementation of nutrients for bacteria (Table 1) [2, 16]. Unfortunately, these conditions were not sufficient to obtain satisfactory results. The spontaneous MLF process brought about an average reduction in malic acid concentration by $39.95 \%$ (Fig. 3), a reduction in total acidity from 2.12 to $2.82 \mathrm{~g} / \mathrm{L}$ as tartaric acid, and an increase in $\mathrm{pH}$ from 0.06 to 0.18 (Table 5).

Taking into account the effectiveness of deacidification of the applied vinification techniques, the tested variants can be lined up in the following order: COI $>$ SEQI $>$ SPONT $>$ AF (Fig. 3). The highest dynamics and yield of malic to lactic acid bioconversion were observed during the simultaneous alcoholic and malolactic fermentation. With co-inoculation, the reduction in the concentration of malic acid varied from 83.97 to $94.84 \%$, and the yield varied from 71.48 to $85.32 \%$ of the theoretical value (Fig. 3). The same variant had the greatest reduction in total acidity (from 2.99 to $3.68 \mathrm{~g} / \mathrm{L}$ ) and the greatest increase in $\mathrm{pH}$ (from 0.34 to 0.43) (Table 5). Likewise, Munoz et al. [34] have reported a greater reduction in the level of malic acid with simultaneous alcoholic and malolactic fermentations than in the case of sequential bacteria inoculation (in the middle and at the end of alcoholic fermentation). Similar observations have also been made by Jussier et al. [18] in the production of Chardonnay from grapes grown in cool-climate regions. The initial malic acid concentration did not influence the effectiveness of MLF $(P>0.05)$.

Complete conversion of all malic acid was not obtained in any of the wines studied in this work. The
Fig. 1 Changes in the concentrations of malic and lactic acid under vinification of white wines (Chardonnay 2009 and Kerling 2010) with different MLF scenarios: only alcoholic fermentation (AF, filled diamond), co-inoculation of yeast and bacteria (COI, filled square), sequential inoculation: bacteria after $\mathrm{AF}$ completion (SEQI, filled triangle), and spontaneous MLF (SPONT, filled circle)
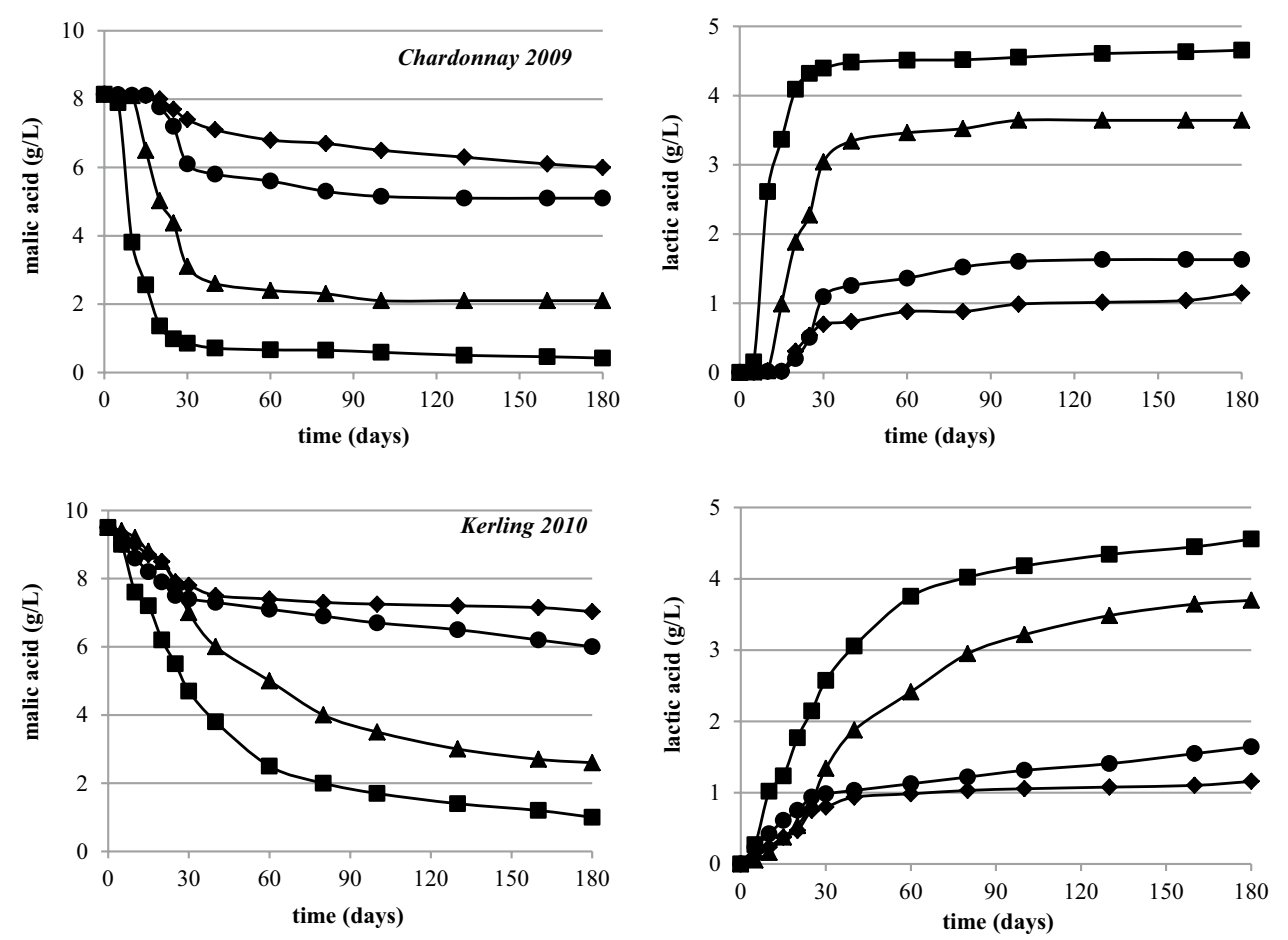
Fig. 2 Changes in the concentrations of malic and lactic acid under vinification of red wines (Pinot noir 2009 and 2012 and Rondo 2012) with different MLF scenarios: only alcoholic fermentation (AF, filled diamond), co-inoculation of yeast and bacteria (COI, filled square), sequential inoculation: bacteria after $\mathrm{AF}$ completion (SEQI, filled triangle), and spontaneous MLF (SPONT, filled circle)
Fig. 3 Final reduction in malic acid expressed in \% (a) and the $\%$ of MLF theoretical yield (b) after 180 days of vinification with different MLF scenarios: only alcoholic fermentation (AF, filled diamond), co-inoculation of yeast and bacteria (COI, filled square), sequential inoculation: bacteria after AF completion (SEQI, filled triangle), and spontaneous MLF (SPONT, filled circle)
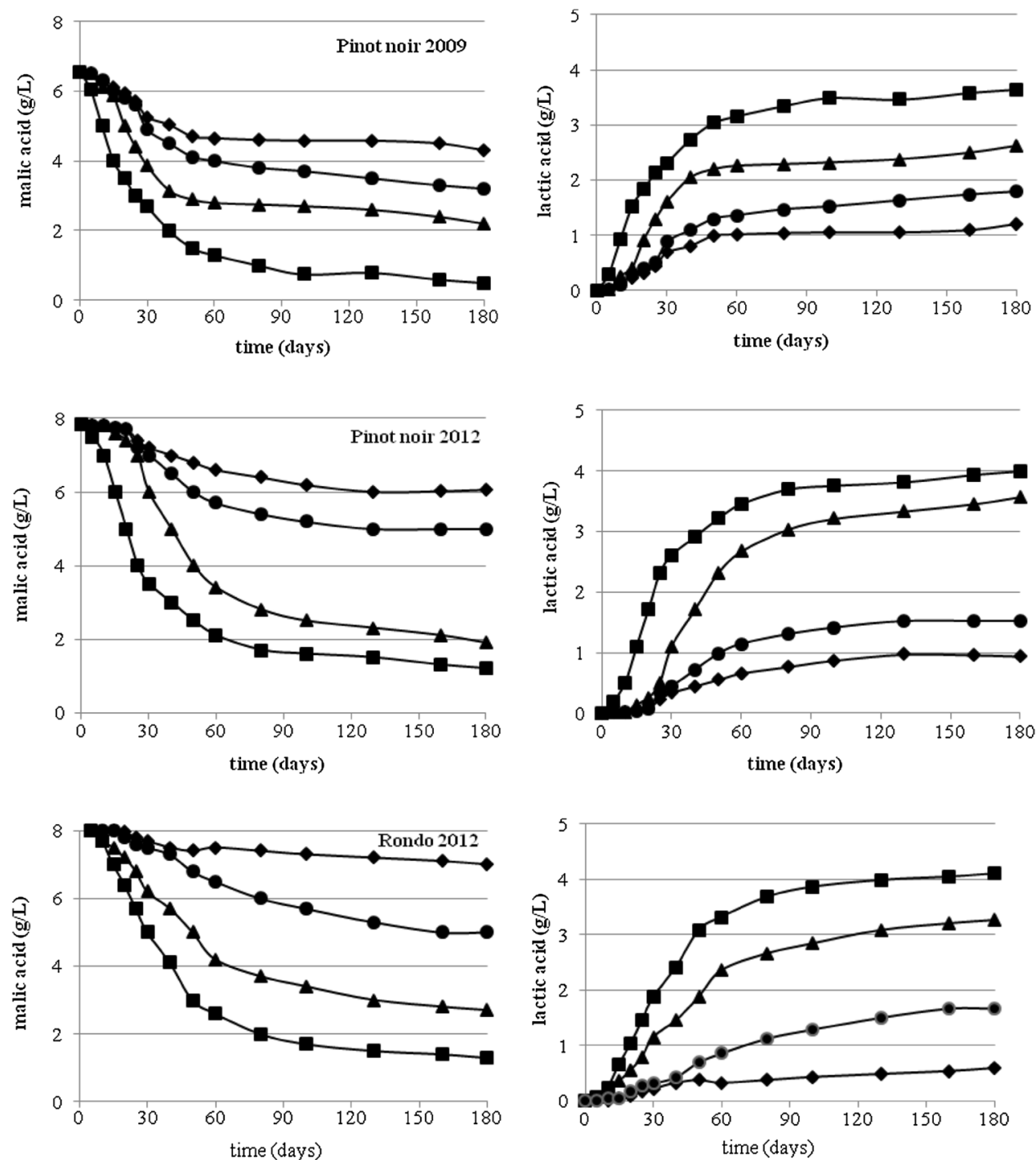

A

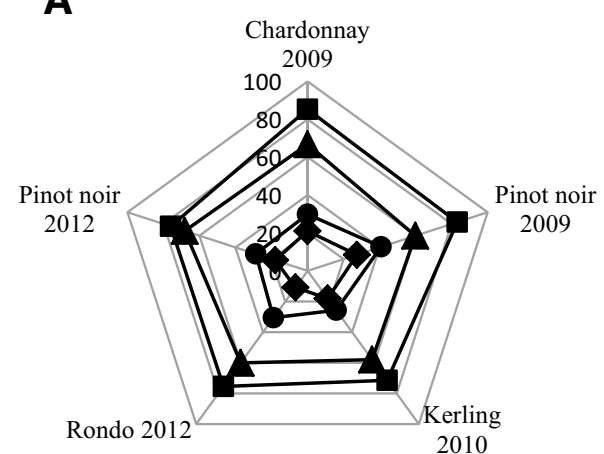

B

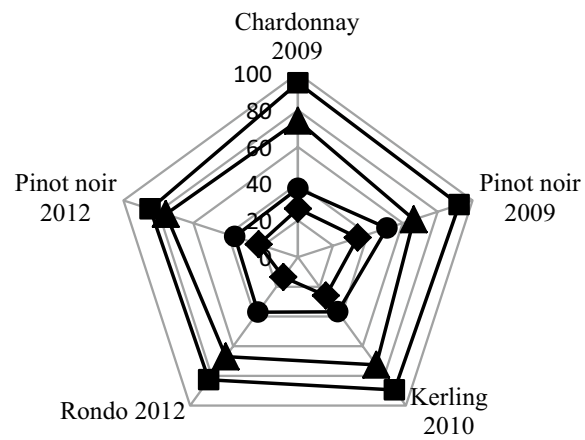

lowest final malic acid concentration (from 0.42 to $1.33 \mathrm{~g} / \mathrm{L}$ ) was reached in the variant with the simultaneous alcoholic and malolactic fermentations (Figs. 1, 2). Tristezza et al. [39] have also reported that they did not obtain complete conversion of malic acid. A few authors have described an almost complete reduction in malic acid concentration, but it should be noted that, in these studies, the initial concentration of malic acid was much 
Table 5 The $\mathrm{pH}$, total, and volatile acidity of the final wines after 180 days of vinification

\begin{tabular}{|c|c|c|c|c|c|}
\hline \multirow[t]{2}{*}{ Wine } & \multicolumn{2}{|l|}{$\mathrm{pH}$} & \multicolumn{2}{|c|}{ Total acidity $(\mathrm{g} / \mathrm{L})^{*}$} & \multirow[t]{2}{*}{ Volatile acidity $(\mathrm{g} / \mathrm{L})^{* *}$} \\
\hline & Final pH & Increase in $\mathrm{pH}$ (final-initial) & final & Reduction (initial-final) & \\
\hline \multicolumn{6}{|c|}{ Chardonnay 2009} \\
\hline $\mathrm{AF}$ & $3.36 \pm 0.03^{\mathrm{c}}$ & 0.05 & $9.27 \pm 0.09^{\mathrm{c}}$ & 2.37 & $0.73 \pm 0.05^{\mathrm{a}}$ \\
\hline COI & $3.65 \pm 0.05^{\mathrm{a}}$ & 0.34 & $7.96 \pm 0.06^{\mathrm{a}}$ & 3.68 & $0.68 \pm 0.08^{\mathrm{a}}$ \\
\hline SEQI & $3.49 \pm 0.08^{\mathrm{b}}$ & 0.18 & $8.18 \pm 0.06^{\mathrm{b}}$ & 3.46 & $0.71 \pm 0.03^{\mathrm{a}}$ \\
\hline SPONT & $3.37 \pm 0.02^{\mathrm{c}}$ & 0.06 & $9.19 \pm 0.11^{\mathrm{c}}$ & 2.45 & $0.84 \pm 0.06^{\mathrm{b}}$ \\
\hline \multicolumn{6}{|c|}{ Pinot noir 2009} \\
\hline $\mathrm{AF}$ & $3.70 \pm 0.04^{\mathrm{d}}$ & 0.06 & $7.66 \pm 0.05^{\mathrm{d}}$ & 1.72 & $0.45 \pm 0.07^{\mathrm{b}}$ \\
\hline $\mathrm{COI}$ & $4.01 \pm 0.03^{\mathrm{a}}$ & 0.37 & $6.39 \pm 0.08^{\mathrm{a}}$ & 2.99 & $0.52 \pm 0.09^{\mathrm{b}}$ \\
\hline SEQI & $3.92 \pm 0.01^{\mathrm{b}}$ & 0.28 & $6.87 \pm 0.09^{\mathrm{b}}$ & 2.51 & $0.36 \pm 0.04^{\mathrm{a}}$ \\
\hline SPONT & $3.78 \pm 0.02^{\mathrm{c}}$ & 0.14 & $7.26 \pm 0.11^{\mathrm{c}}$ & 2.12 & $0.68 \pm 0.05^{\mathrm{c}}$ \\
\hline \multicolumn{6}{|c|}{ Kerling 2010} \\
\hline $\mathrm{AF}$ & $3.28 \pm 0.01^{\mathrm{d}}$ & 0.09 & $9.44 \pm 0.05^{\mathrm{d}}$ & 2.7 & $0.67 \pm 0.05^{\mathrm{c}}$ \\
\hline COI & $3.58 \pm 0.01^{\mathrm{a}}$ & 0.39 & $8.67 \pm 0.08^{\mathrm{a}}$ & 3.47 & $0.39 \pm 0.08^{\mathrm{a}}$ \\
\hline SEQI & $3.41 \pm 0.03^{\mathrm{b}}$ & 0.22 & $8.92 \pm 0.07^{\mathrm{b}}$ & 3.22 & $0.48 \pm 0.06^{\mathrm{b}}$ \\
\hline SPONT & $3.35 \pm 0.03^{c}$ & 0.16 & $9.32 \pm 0.07^{\mathrm{c}}$ & 2.82 & $0.76 \pm 0.04^{\mathrm{d}}$ \\
\hline \multicolumn{6}{|c|}{ Pinot noir 2012} \\
\hline $\mathrm{AF}$ & $3.50 \pm 0.03^{\mathrm{d}}$ & 0.09 & $8.88 \pm 0.13^{\mathrm{c}}$ & 2.07 & $0.39 \pm 0.05^{\mathrm{a}}$ \\
\hline $\mathrm{COI}$ & $3.82 \pm 0.02^{\mathrm{a}}$ & 0.41 & $7.44 \pm 0.07^{\mathrm{a}}$ & 3.51 & $0.42 \pm 0.07^{\mathrm{ab}}$ \\
\hline SEQI & $3.77 \pm 0.01^{\mathrm{b}}$ & 0.36 & $7.59 \pm 0.05^{b}$ & 3.36 & $0.45 \pm 0.03^{b}$ \\
\hline SPONT & $3.55 \pm 0.02^{c}$ & 0.14 & $8.81 \pm 0.14^{\mathrm{c}}$ & 2.14 & $0.63 \pm 0.04^{\mathrm{c}}$ \\
\hline \multicolumn{6}{|c|}{ Rondo 2012} \\
\hline $\mathrm{AF}$ & $3.31 \pm 0.03^{\mathrm{d}}$ & 0.05 & $8.99 \pm 0.11^{\mathrm{c}}$ & 2.53 & $0.48 \pm 0.06^{\mathrm{a}}$ \\
\hline $\mathrm{COI}$ & $3.69 \pm 0.04^{\mathrm{a}}$ & 0.43 & $7.79 \pm 0.06^{\mathrm{a}}$ & 3.58 & $0.57 \pm 0.02^{\mathrm{b}}$ \\
\hline SEQI & $3.51 \pm 0.02^{\mathrm{b}}$ & 0.25 & $8.4 \pm 0.09^{b}$ & 3.12 & $0.55 \pm 0.04^{\mathrm{ab}}$ \\
\hline SPONT & $3.44 \pm 0.02^{\mathrm{c}}$ & 0.18 & $8.91 \pm 0.09^{c}$ & 2.61 & $0.69 \pm 0.02^{\mathrm{c}}$ \\
\hline
\end{tabular}

Values are the mean of triplicates $\pm \mathrm{SD}$

* As tartaric acid $(\mathrm{g} / \mathrm{L})$

** As acetic acid $(\mathrm{g} / \mathrm{L})$

(a,b,c,d) Denotes statistically significant differences $(P<0.05)$ between the different MLB inoculation scenarios

lower (ranging from 1.15 to $2.55 \mathrm{~g} / \mathrm{L}$ ) [1, 8, 14, 30, 43] than in the musts studied here (Table 2).

Lactic acid is known for its antimicrobial activity, so it can be expected that, in higher concentrations, it might show an inhibitory effect also against MLB. Given this, it can be assumed that the malolactic activity of $O$. oeni may be inhibited above a certain lactic acid concentration. Thus, it can be postulated that in case of high-acid musts, a total reduction in malic acid can be not possible.

\section{Citric and acetic acid metabolism}

Apart from malic acid, the concentrations of citric and acetic acid also have a significant influence on the quality of wine. In the MLF process, citric acid can be metabolized to pyruvate, lactate, acetate, ethanol, and diacetyl. From the perspective of wine quality, the bioconversion of citric acid to acetic acid and diacetyl is particularly adverse. Acetic acid concentrations are limited by strict quality standards, and this acid is responsible for a vinegary aroma and taste, which disqualifies the wine $[25,38]$. Small concentrations of diacetyl give pleasant, delicate notes of nuts, caramel, and a pleasing buttery taste. However, in higher concentrations (above $1 \mathrm{mg} / \mathrm{L}$ ), it is responsible for less pleasant intensely buttery tones $[11,12,15,21,23,25,28,35]$. The metabolites are mainly produced by bacteria involved in spontaneous MLF-namely Pediococcus, Lactobacillus, and Leuconostoc. The $O$. oeni bacteria synthesize these metabolites in trace and acceptable amounts, so the use of the inoculation process with properly chosen starter cultures seems satisfactory to protect the vinification process and the resulting wine $[11,12,15,21,25,41]$. 
To date, the literature reports on citric acid metabolism in the process of vinification are inconsistent and more information is needed. Canas et al. [8] have demonstrated that a significantly higher reduction in citric acid concentration results upon sequential inoculation of malolactic bacteria than with the co-inoculation method; however, there was no considerable effect on volatile acidity. Zaparolli et al. [43] did not report any effect of the timing of inoculation with $O$. oeni on the concentration of citric acid. In the wines they studied, the amount of citric acid did not differ significantly from its concentration in the musts. However, Abrahamse and Bartowsky [1], in a similar study, noted full conversion of citric acid. The differences between the results in the literature may indicate that citric acid metabolism depends on the strain of the bacteria $O$. oeni involved in MLF and on the parameters of the process (type of must, temperature, $\mathrm{SO}_{2}$ concentration, time of inoculation, amount of bacteria inoculated, etc.).

In our studies, a reduction in the amount of citric acid was recorded only in the process of spontaneous MLF. In this process, the reduction in the citric acid concentration ranged from 26.8 to $39.3 \%$. In the other variants of the vinification process, the concentration of citric acid did not change (Table 4). Heterofermentative bacteria of lactic fermentation, including $O$. oeni, can also use hexose sugars to produce D-lactic acid, $\mathrm{CO}_{2}$, and acetic acid [11, 29]. Some authors have thus suggested that MLF can increase the volatile acidity of wine to unacceptable levels, from the point of view of both taste and standards [11, 15, 25].

It should be pointed out, however, that the increase in volatile acidity caused by MLF has been observed mostly as a result of spontaneous fermentations and the metabolism of wild malolactic bacteria. Recently, an increasing number of authors have reported small differences in the acetic acid concentrations of wines produced using $O$. oeni bacteria. Almost always, the level of acetic acid has been below the admissible limit and did not affect the quality and aroma of the wines [5, 18, 30, 34]. In our study, when evaluating the effect of MLF on the final concentration of acetic acid, the worst results were obtained for the spontaneous malolactic fermentation variant. Indeed, the volatile acidity was significantly higher than for the other variants, but did not exceed $0.84 \mathrm{~g} / \mathrm{L}$ (expressed as acetic acid) (Table 5), which meets the standards for good-quality grape wine. For the other wines, no distinct trend of changes was seen in volatile acidity depending on the vinification technology used. With the control variant (AF only), the volatile acidity did not exceed $0.73 \mathrm{~g} / \mathrm{L}$; with the simultaneous $\mathrm{AF}$ and MLF (COI) variant, it did not exceed $0.68 \mathrm{~g} / \mathrm{L}$; and with the sequential inoculation (SEQI), the highest concentration was $0.71 \mathrm{~g} / \mathrm{L}$ (Table 5).

Abrahamse and Bartowsky [1] have also reported that the timing of malolactic bacteria inoculation has no effect on the volatile acidity of the wine, but the concentration of acetic acid in the wine they studied was more than twice as high as in the alcoholic fermentation variant $(0.94-0.96 \mathrm{~g} / \mathrm{L}$ depending on inoculation time; $0.45 \mathrm{~g} / \mathrm{L}$ with no MLF). Tristezza et al. [39] reported a significant reduction in volatile acidity $(0.30-0.31 \mathrm{~g} / \mathrm{L})$ as a result of simultaneous yeast and bacteria inoculation, in comparison to sequential inoculation $(0.49-0.51 \mathrm{~g} / \mathrm{L})$. A similar trend was noted by Knoll et al. [19] in the vinification of cool-climate Riesling: for the four MLF inoculation timings tested $(24 \mathrm{~h}$ after yeast inoculation and after 40,60 , and $100 \%$ of alcoholic fermentation completion), the concentration of acetic acid in the final wine increased from 0.61 to $0.77 \mathrm{~g} / \mathrm{L}$, respectively.

This insignificant increase in the concentration of acetic acid in the wines produced with MLF may be not only a result of the bacteria metabolism, but also of the yeast metabolism. It has already been shown that, under stressful conditions, yeast produces a higher amount of acetic acid than under optimal conditions [13]. It is also highly probable that the production of acetic acid during vinification has a strain-dependent (for both yeast and bacteria) and environment-dependent character [39].

\section{Conclusions}

Of the four malolactic bacteria inoculation scenarios tested for use in the vinification process of high-acid musts (with enhanced concentrations of malic acid), the simultaneous inoculation of yeast and bacteria seems to be preferable as it results in the most effective MLF process and the best quality parameters of wine.

In contrast to the prevailing opinion that co-inoculation can result in a disadvantageous increase in volatile acidity, wines obtained with this technique showed no increase in volatile acidity and also showed the lowest concentrations of residual sugars, which is directly related to enhanced microbiological stability and protects against the overproduction of undesirable metabolites.

The timing of malolactic bacteria inoculation had no effect on the metabolism of citric and acetic acids. A significant reduction in the concentration of citric acid and an increase in the volatile acidity were observed only for the spontaneous MLF variant. This confirms the opinion that wine produced through a non-inoculated process (with native MLB) can excessively accumulate undesirable metabolites.

The same dependencies were observed in the three following wine seasons, which allows us to postulate that the simultaneous inoculation of yeast and bacteria is very beneficial in vinifying high-acid grapes. The results and relations presented here facilitate the modeling and optimization of the vinification of uncommon grapes, especially 
those cultivated in cool seasons or in cool-climate regions, like Central Europe.

Acknowledgements This work was supported by the research Grant from the National Research Centre (Poland)_Project No. NN312 206036.

\section{Compliance with ethical standards}

Conflict of interest The authors declare that they have no conflict of interest.

Compliance with ethics requirements This article does not contain any studies with human or animal subjects.

Open Access This article is distributed under the terms of the Creative Commons Attribution 4.0 International License (http://creativecommons.org/licenses/by/4.0/), which permits unrestricted use, distribution, and reproduction in any medium, provided you give appropriate credit to the original author(s) and the source, provide a link to the Creative Commons license, and indicate if changes were made.

\section{References}

1. Abrahamse CE, Bartowsky EJ (2012) Timing of malolactic fermentation inoculation in Shiraz grape must and wine: influence on chemical composition. World J Microbiol Biotechnol 28:255-265

2. Alexandre HPJ, Costello F, Remize J, Guzzo Guilloux-Benatier M (2004) Saccharomyces cerevisiae-Oenococcus oeni interactions in wine: current knowledge and perspectives. Int J Food Microbiol 93:141-154

3. Araque I, Gil J, Carrete R, Bordons A, Reguant C (2009) Detection of arc genes related with the ethyl carbamate precursors in wine lactic acid bacteria. J Agric Food Chem 57:1841-1847

4. Arnink K, Henick-Kling T (2005) Influence of Saccharomyces cerevisiae and Oenococcus oeni strains on successful malolactic conversion of wine. Am J Enol Vitic 56:228-237

5. Azzolini M, Tosi E, Vagnoli P, Krieger S, Zaparolli G (2010) Evaluation of technological effects of yeast-bacterial co-inoculations in red table wine production. Ital J Food Sci 3:257-263

6. Bauer R, Dicks IMT (2004) Control of malolactic fermentation in wine. A review. S Afr J Enol Vitic 25:74-88

7. Bisson L, Butzke C (2000) Diagnosis and rectification of stuck and sluggish fermentations. Am J Enol Vitic 51:138-177

8. Canas PMI, Perez-Martin F, Romero EG, Prieto SS, Herreros MLP (2012) Influence of inoculation time of an autochthonous selected malolactic bacterium on volatile and sensory profile of Tempranillo and Merlot wines. Int J Food Microbiol $156: 245-254$

9. Capozzi V, Russo P, Beneduce L, Weidmann S, Grieco F, Guzzo J, Spano G (2010) Technological properties of Oenococcus oeni strains isolated from typical southern Italian wines. Lett Appl Microbiol 50:327-334

10. Costello PJ, Henschke PA, Markides AJ (2003) Standardised methodology for testing malolactic bacteria and wine yeast compatibility. Aust J Grape Wine Res 9:127-137

11. Davis CR, Wibowo D, Eschenbruch R, Lee TH, Fleet GH (1985) Practical implications of malolactic fermentations: a review. Am J Enol Vitic 36:290-301
12. Davis CR, Wibowo D, Fleet GH, Lee TH (1988) Properties of wine lactic acid bacteria: their potential enological significance. Am J Enol Vitic 39:137-142

13. Erasmus DJ, Cliff M, Van Vuuren HJJ (2004) Impact of yeast strain on the production of acetic acid, glycerol and the sensory attributes of icewine. Am J Enol Vitic 55:371-378

14. Guzzon R, Malacarne M, Moser S, Larcher R (2015) Together is better. Experience of simultaneous fermentation of yeast and bacteria as a possible strategy to prevent stuck fermentation in difficult wines. Wine Stud 4:4941

15. Henick-Kling T (1993) Malolactic fermentation. In: Fleet GH (ed) Wine microbiology and biotechnology. Harwood Academic Publishers, New York, pp 289-327

16. Henick-Kling T, Park YH (1994) Considerations for the use of yeast and bacterial starter cultures: $\mathrm{SO}_{2}$ and timing of inoculation. Am J Enol Vitic 45:464-469

17. Izquierdo Canas PM, Romero G, Perez-Martin F, Prieto S, Palop Herreros MI (2014) Sequential inoculation versus coinoculation in Cabernet Franc wine fermentation. Food Sci Technol Int 21:1-10

18. Jussier D, Morneau AD, Mira de Orduna R (2006) Effect of simultaneous inoculation with yeast and bacteria on fermentation kinetics and key wine parameters in cool climate Chardonnay. Appl Environ Microbiol 72:221-227

19. Knoll C, Fritsch S, Schnell S, Grossmann M, Krieger-Weber S, du Toit M, Rauhut D (2012) Impact of different malolactic fermentation inoculation scenarios on Riesling wine aroma. World J Microbiol Biotechnol 28:1143-1153

20. Krieger-Weber S (2009) Application of yeast and bacteria as starter cultures. In: Konig H, Unden G, Fruchlich J (eds) Biology of microorganisms on grapes, in must and in wine. Springer, Berlin, pp 489-513

21. Kunkee RE (1999) Some roles of malic acid in the malolactic fermentation in wine making. FEMS Microbiol Lett 88:55-71

22. Landete JM, Ferrer S, Pardo I (2007) Biogenic amine production by lactic acid bacteria, acetic bacteria and yeast isolated from wine. Food Control 18:1569-1574

23. Lerm E, Engelbrech L, du Toit M (2010) Malolactic fermentation: the ABC's of MLF. S Afr J Enol Vitic 31:186-212

24. Lasik M (2013) The application of malolactic fermentation process to create good-quality grape wine produced in cool-climate countries: a review. Eur Food Res Technol 237:843-850

25. Lonvaud-Funel A (1999) Lactic acid bacteria in the quality improvement and depreciation of wine. Antonie Van Leeuwenhoek 76:317-331

26. Lonvaud-Funel A (2001) Biogenic amines in wine: role of lactic acid bacteria. FEMS Microbiol Lett 199:9-13

27. Lonvaud-Funel A, Joyeux A, Desens C (1988) The inhibition of malolactic fermentation of wines by products of yeast metabolism. J Food Sci Technol 44:183-191

28. Maicas S, Gil J-V, Pardo I, Ferrer S (1999) Improvement of volatile composition of wines by controlled addition of malolactic bacteria. Food Res Int 32:91-496

29. Maicas S, Ferrer S, Pardo I (2002) NAD (P) H regeneration is the key for heterolactic fermentation of hexoses in Oenococcus oeni. Microbiology 148:325-332

30. Massera A, Soria A, Catania C, Krieger S, Combina M (2009) Simultaneous inoculation of Malbec (Vitis vinifera) musts with yeast and bacteria: effects on fermentation performance, sensory and sanitary attributes of wines. Food Technol Biotechnol 47:192-201

31. Mendoza LM, Merin MG, Morata VI, Farias ME (2011) Characterization of wines produced by mixed culture of autochthonous yeast and Oenococcus oeni from the northwest region of Argentina. J Ind Microbiol Biotechnol 38:1777-1785 
32. Moreno-Arribas MV, Polo MC (2008) Occurrence of lactic acid bacteria and biogenic amines in biologically aged wines. Food Microbiol 25:75-881

33. Mozell MR, Thach L (2014) The impact of climate change on the global wine industry: challenges \& solutions. Wine Econ Policy 3:81-89

34. Munoz V, Beccaria B, Abreo E (2014) Simultaneous and successive inoculations of yeasts and lactic acid bacteria on the fermentation of an unsulfited Tannat grape must. Braz J Microbiol 45:59-66

35. Nielsen JC, Richelieu M (1999) Control of flavor development in wine during and after malolactic fermentation by Oenococcus oeni. Appl Environ Microbiol 65:740-745

36. OIV. The International Organisation of Vine and Wine (2015) Standards and technical documents. Methods of analysis. Compendium of International Methods of Analysis of Wines and Musts

37. Rosi I, Fia G, Canuti V (2003) Influence of different pH values and inoculation time on the growth and malolactic activity of a strain of Oenococcus oeni. Aust J Grape Wine Res 9:194-199

38. Ribereau-Gayon J, Dubourdieu D, Doneche B, Lonvaud A (2006) Lactic acid bacteria. In: Ribereau-Gayon J, Dubourdieu
D, Doneche B, Lonvaud A (eds) Handbook of enology: the microbiology of wine and vinifications, vol 1, 2nd edn. Whiley, London

39. Tristezza M, di Feo L, Tufariello M, Grieco F, Capozzi V, Spano G, Mita G, Grieco F (2016) Simultaneous inoculation of yeasts and lactic acid bacteria: effects on fermentation dynamics and chemical composition of Negroamaro wine. Food Sci Technol 66:406-412

40. Uthurry CA, Suarez Lepe JA, Lombardero J, Garcia Del Hierro JR (2006) Ethyl carbamate production by selected yeasts and lactic acid bacteria in red wine. Food Chem 94:262-270

41. Versari A, Parpinello GP, Cattaneo M (1999) Leuconostoc oenos and malolactic fermentation in wine: a review. J Ind Microbiol Biotechnol 23:447-455

42. Yurdugül S, Bozoglu F (2002) Studies on an inhibitor produced by lactic acid bacteria of wines on the control of malolactic fermentation. Eur Food Res Technol 215:38-41

43. Zaparolli G, Tosi E, Azzolini M, Vagnoli P, Krieger S (2009) Bacterial inoculation strategies for the achievement of malolactic fermentation in high-alcohol wines. S Afr J Enol Vitic 30:49-55 